\title{
Major- and Trace-Element Concentrations in Soils from Two Continental-Scale Transects of the United States and Canada
}

By David B. Smith', William F. Cannon², Laurel G. Woodruff ${ }^{3}$, Robert G. Garrett ${ }^{4}$, Rodney Klassen ${ }^{4}$, James E. Kilburn', John D. Horton ${ }^{5}$, Harley D. King', Martin B. Goldhaber', and Jean M. Morrison'

'U.S. Geological Survey, Denver, Colorado

2U.S. Geological Survey, Reston, Virginia

${ }^{3}$ U.S. Geological Survey, Mounds View, Minnesota

${ }^{4}$ Geological Survey of Canada, Ottawa, Ontario

${ }^{5}$ Environmental Careers Organization, Reston, Virginia

Open-File Report 2005-1253 


\section{U.S. Department of the Interior \\ Gale A. Norton, Secretary}

\section{U.S. Geological Survey \\ P. Patrick Leahy, Acting Director}

U.S. Geological Survey, Reston, Virginia 2005

For product and ordering information:

World Wide Web: http://www.usgs.gov/pubprod

Telephone: 1-888-ASK-USGS

For more information on the USGS - the Federal source for science about the Earth, its natural and living resources, natural hazards, and the environment:

World Wide Web: http://www.usgs.gov

Telephone: 1-888-ASK-USGS

This report has not been reviewed for geologic nomenclature.

Although this report is in the public domain, permission must be secured from the individual copyright owners to reproduce any copyrighted material contained within this report. 


\title{
Major- and Trace-Element Concentrations in Soils from Two Continental-Scale Transects of the United States and Canada
}

\author{
By David B. Smith', William F. Cannon', Laurel G. Woodruff ${ }^{3}$, Robert G. Garrett', Rodney Klassen ${ }^{4}$, \\ James E. Kilburn', John D. Horton', Harley D. King', Martin B. Goldhaber', and Jean M. Morrison'
}

'U.S. Geological Survey, Denver, Colorado

${ }^{2}$ U.S. Geological Survey, Reston, Virginia

${ }^{3}$ U.S. Geological Survey, Mounds View, Minnesota

${ }^{4}$ Geological Survey of Canada, Ottawa, Ontario

${ }^{5}$ Environmental Careers Organization, Reston, Virginia

\section{Abstract}

This report contains major- and trace-element concentration data for soil samples collected from 265 sites along two continental-scale transects in North America. One of the transects extends from northern Manitoba to the United States-Mexico border near El Paso, Tex. and consists of 105 sites. The other transect approximately follows the 38th parallel from the Pacific coast of the United States near San Francisco, Calif., to the Atlantic coast along the Maryland shore and consists of 160 sites. Sampling sites were defined by first dividing each transect into approximately $40-\mathrm{km}$ segments. For each segment, a 1-km-wide latitudinal strip was randomly selected; within each strip, a potential sample site was selected from the most representative landscape within the most common soil type. At one in four sites, duplicate samples were collected 10 meters apart to estimate local spatial variability. At each site, up to four separate soil samples were collected as follows: (1) material from 0-5 cm depth; (2) O horizon, if present; (3) a composite of the A horizon; and (4) C horizon. Each sample collected was analyzed for total major- and trace-element composition by the following methods: (1) inductively coupled plasmamass spectrometry (ICP-MS) and inductively coupled plasma-atomic emission spectrometry (ICPAES) for aluminum, antimony, arsenic, barium, beryllium, bismuth, cadmium, calcium, cerium, cesium, chromium, cobalt, copper, gallium, indium, iron, lanthanum, lead, lithium, magnesium, manganese, molybdenum, nickel, niobium, phosphorus, potassium, rubidium, scandium, silver, sodium, strontium, sulfur, tellurium, thallium, thorium, tin, titanium, tungsten, uranium, vanadium, yttrium, and zinc; (2) cold vapor- atomic absorption spectrometry for mercury; (3) hydride generation-atomic absorption spectrometry for antimony and selenium; (4) coulometric titration for carbonate carbon; and (5) combustion for total carbon and total sulfur. 


\section{Introduction}

Our understanding of the variability in chemical composition of the soils on the North American continent is very limited. Neither Canada nor Mexico has a national-scale soil geochemical database. The United States has two such national-scale databases, but each has its shortcomings.

The earliest such database was generated for the conterminous United States (U.S.) by the U.S. Geological Survey (USGS) in an effort initiated in the mid-1960s and completed in the late 1970s (Shacklette and others, 1971a, 1971b, 1973, 1974; Boerngen and Shacklette, 1981; Shacklette and Boerngen, 1984). This data set commonly is referred to as the "Shacklette data" because the effort was conceived and coordinated by H.T. Shacklette. The purpose of this study was to provide estimates of the range of element abundance in soils that generally were unaffected by human activities. This data set consists of only 1,323 samples, representing a density of approximately 1 sample per 6,000 square kilometers (2,300 square miles). The samples mostly were collected from fields sustaining native vegetation. The sampling protocol called for removal of loose organic debris from the surface and then collection of soil from a depth of $0-20 \mathrm{~cm}$. The samples were analyzed for about 40 elements by a combination of methodologies available at that time. The resulting data set is still the most-often-quoted reference for estimating background concentrations of trace elements in soils of the conterminous U.S. New map presentations for 22 elements from this data set were published by Gustavsson and others (2001). A similar low-density geochemical survey was conducted in Alaska following the same protocols (Gough and others, 1984, 1988).

The other national-scale soil geochemical database for the conterminous U.S. was generated by the Natural Resources Conservation Service (NRCS), formerly the Soil Conservation Service (Holmgren and others, 1993). The purpose of this study, initiated in 1978, was to establish the background levels of cadmium and lead in major food crops and in the soils of their major growing areas. The resulting data set consists of 3,045 surface soil samples analyzed for only five elements (cadmium, lead, zinc, copper, and nickel).

While both the USGS and NRCS national-scale soil geochemical databases have been tremendously useful, there are deficiencies in each. The USGS data set is of extremely low density, and better analytical methods now are available for many of the elements analyzed. The NRCS data set only has data for five elements and only represents major crop-producing areas of the conterminous U.S. In summary, the existing national-scale soil geochemical data for the U.S., and certainly for North America, is inadequate for addressing the current and future needs of environmental regulators, risk assessment specialists engaged in risk-based assessment of contaminated land, and the public health sector.

In 2003, the USGS, in collaboration with partners in Canada (Geological Survey of Canada; Agriculture and Agri-Food Canada) and Mexico (Consejo de Recursos Minerales/Servicio

Geológico de México; Instituto Nacional de Estadística Geografia e Informática), initiated a project called Geochemical Landscapes that has as its long-term goal a soil geochemical survey of North America. In 2004, the project entered a pilot phase in which samples were collected along two continental-scale transects. The purpose of this report is to summarize the project activities leading up to and through this pilot phase and to release the major- and trace-element geochemical data generated. 


\section{The Geochemical Landscapes Project}

The project was officially launched with the Soil Geochemistry Workshop held in Denver, Colo., on March 4-6, 2003. This workshop attracted 112 attendees representing 41 Federal and State governmental agencies, academic institutions, environmental consulting firms, and the public health and medical community. Three agencies from Canada and one from Mexico were represented. Workshop participants were asked to develop recommendations concerning the design, sampling, and analytical protocols for a continental-scale soil geochemical survey. Complete reports from the workshop are available online at http://gswiki.usgs.gov/soils/ (accessed on July 5, 2005). Brief summaries of the recommendations are given below.

\section{Sample Design}

The stated objective for the proposed continental-scale survey was recommended to be the determination of the unbiased geochemical status of all North American soils. Thus, the target population is all soils of the North American continent as opposed to only agricultural soils as in the NRCS national-scale data set or only nonagricultural soils as in the USGS national-scale data set. After consideration of many options for a stratified design, it was recommended that sampling occur on the basis of a uniform grid of about 10,000 sites for the continent. This is a density of about one sample per 2,000 square kilometers (770 square miles) or about 3 times that of the Shacklette data.

\section{Sample Collection Protocol}

The workshop participants recommended a combination of depth-based and horizon-based sampling at each of the proposed 10,000 sites. The members of the workshop from the public health sector were vocal in their support of collecting the top $5 \mathrm{~cm}$ (2 in) at each site. This is the material with which humans regularly come into contact during the course of a normal day's activity and, thus, is most important in issues relating to chronic exposure through ingestion, inhalation, or dermal contact. In addition to this surficial layer of soil, collection of a representative sample of the following soil horizons was recommended: O horizon (if present), A horizon, B horizon, and $\mathrm{C}$ horizon or parent material.

\section{Analytical Protocols}

\section{Major and trace elements}

The participants in the workshop felt the most important chemical measurement for the samples collected in a continental-scale soil geochemical survey is the total elemental composition. It was recommended that the primary analytical protocol should be a combination of inductively coupled plasma-mass spectrometry (ICP-MS) for trace elements and inductively coupled plasmaatomic emission spectrometry (ICP-AES) for major elements following a four-acid (hydrochloric, nitric, hydrofluoric, perchloric) digestion. This methodology offers the combination of high throughput, excellent sensitivity, and a broad range of analytes (42 elements). This technique would be supplemented by single element determinations for mercury, selenium, antimony, forms of carbon, and total sulfur. In addition, a subset of samples should be analyzed following a digestion using a sintering procedure. This procedure is more effective at dissolving elements such as zirconium, niobium, and tantalum hosted by refractory minerals such as zircon. Also, a subset of samples should be analyzed by nondestructive methods such as X-ray fluorescence (XRF) or 
instrumental neutron activation analysis (INAA). These data would provide benchmarks against which the primary analytical protocol could be judged.

\section{Soil Characterization Analysis}

Soil characterization parameters needed to help interpret the chemical data generated by the above methods include field moisture content; bulk density; soil pH; cation exchange capacity; particle size analysis; and citrate-dithionite-extractable iron, aluminum, and manganese. In addition, clay mineralogy should be done by X-ray diffraction analysis on a subset of samples.

\section{Bioaccessibility determinations}

In environmental risk-based decision making, it often is more important to know the bioaccessible fraction of elements and chemical species in soils than the total elemental content. In this regard, recommendations from the workshop included bioaccessibility determinations by two extractions - a simple water extraction and a simulated human gastric fluid.

\section{Organic compounds}

Analysis of organic compounds in regional-, national-, and international-scale geochemical surveys has historically been neglected because of the high cost. However, given the potential effect of synthetic organic chemicals on human, animal, and ecosystem health, the workshop participants felt it was critical to address this issue at some level in the proposed survey of North America. It was recommended that a subset of samples be analyzed for selected organic compounds to address two themes: (1) long-range transport of persistent organic pollutants, and (2) distribution of major pesticides and their transformation products.

\section{Soil microbiology}

It was the consensus of the workshop attendees that soil microbiology should be incorporated at least into the pilot studies to determine if such studies at a continental scale would be feasible or would yield meaningful results in terms of stable patterns of microbial characteristics. The recommendation was to use two complementary methods. Phospholipid fatty acid analysis (PLFA) would provide a measure of microbial biomass as well as markers for major groups of organisms (i.e., patterns of microbial ecology). DNA fingerprinting has the potential to provide both patterns of microbial ecology and identify specific organisms. In addition, this method might be used to test for the presence of specific pathogens (e.g., anthrax) in soil.

\section{Pilot Studies}

In 2004, the Geochemical Landscapes Project entered into a 3-year pilot phase to test and refine the above protocols and to establish logistics for a soil geochemical survey of North America. Two pilot studies were identified-one at a true continental scale and the other at a regional scale. The continental-scale study consists of sampling along two transects (fig. 1). The $\mathrm{N}-\mathrm{S}$ transect extends from northern Manitoba to the U.S.-Mexico border near El Paso, Tex. The EW transect follows the $38^{\text {th }}$ parallel from the Pacific coast north of San Francisco to the Atlantic coast along the Maryland shore. The regional-scale pilot study is being conducted in an area of about 12,000 square miles in northern California and will be the subject of future reports. This document focuses exclusively on the continental-scale study. 


\section{Selection of Transect Routes}

The transects were located to cross multiple climatic, topographic, physiographic, land use, geologic, pedologic, and ecological boundaries. This imposes rigorous field testing of sampling protocols across a wide range of conditions. The generated data will allow estimation of geochemical and microbiological variation at a continental scale.

\section{Selection of Sample Sites}

Each transect was divided into approximately 40-km segments. For each segment, a 1-kmwide latitudinal strip was randomly selected; within each strip, a potential sample site was selected from the most representative landscape within the most common soil type. At one in four sites, duplicate samples were collected 10 meters apart to estimate local spatial variability. The N-S transect consists of 105 sites, and the E-W transect has 160 sites.

\section{Sample-Collection Protocol}

The sampling protocol for the continental-scale transects was modified slightly from the protocol recommended at the Soil Geochemistry Workshop. The focus for the transects was discriminating between human influence on soil geochemistry and geologic influence. Human influence is potentially shown in the $0-5-\mathrm{cm}$ material, the $\mathrm{O}$ horizon (where present), and the $\mathrm{A}$ horizon. The geologic influence, while important in all samples, is most represented free of human influence in the $\mathrm{C}$ horizon. No B-horizon material was collected at any of the transect sites. At each site, an additional sample of $0-5-\mathrm{cm}$ material was collected for analysis of organic compounds, and an additional sample of A-horizon material was collected for microbial characterization. Detailed protocols used by the field sampling teams are given in Appendix I of this report.

\section{Sample Preparation}

Mineral soils were disaggregated and sieved through a 2-mm stainless steel screen. The less-than-2-mm material was crushed to less than 100 mesh $(<150 \mu \mathrm{m})$ in a ceramic mill and thoroughly mixed to ensure homogeneity prior to chemical analysis. Soils containing significant organic matter (O-horizon samples and $0-5 \mathrm{~cm}$ material collected at sites with an $\mathrm{O}$ horizon) also were disaggregated and sieved as above. The less-than-2-mm material then was split prior to chemical analysis. One split was ashed at $450^{\circ} \mathrm{C}$ to remove the organic matter and then submitted for analysis by ICP-AES and ICP-MS. The second split was not ashed, and was analyzed by the other methods described below. Samples within each horizon or depth interval were randomized prior to chemical analysis to avoid confusing spatial variation with any possible systematic bias within a given analytical technique. This randomization does not eliminate a systematic error, but the error is effectively transformed into one that is random with respect to geographic location (Tidball, 1984).

\section{Analytical Protocols}

The focus of this report is only on the release of major- and trace-element analysis. Data for organic compounds, microbial characterization, and other determinations will be released in future documents.

Forty-two major and trace elements were determined by a combination of ICP-MS and ICPAES (Briggs and Meier, 1999). The samples were decomposed using a mixture of hydrochloric, nitric, perchloric, and hydrofluoric acids at low temperature. An aliquot of each sample then was 
aspirated into ICP-MS and ICP-AES instruments. Table 1 shows the elements analyzed and the reporting range for each element.

Table 1. Elements determined by ICP-MS and ICP-AES with their upper and lower reporting limits.

\begin{tabular}{|c|c|c|}
\hline Element & Lower reporting limit & Upper reporting limit \\
\hline Aluminum, $\mathrm{Al}$ & $0.01 \%$ & $15 \%$ \\
\hline Calcium, Ca & $0.01 \%$ & $15 \%$ \\
\hline Iron, Fe & $0.01 \%$ & $15 \%$ \\
\hline Potassium, $\mathrm{K}$ & $0.01 \%$ & $15 \%$ \\
\hline Magnesium, Mg & $0.01 \%$ & $15 \%$ \\
\hline Sodium, $\mathrm{Na}$ & $0.01 \%$ & $15 \%$ \\
\hline Phosphorus, $\mathrm{P}$ & $50 \mathrm{ppm}$ & $1 \%$ \\
\hline Titanium, $\mathrm{Ti}$ & $0.01 \%$ & $15 \%$ \\
\hline Silver, Ag & $1 \mathrm{ppm}$ & $10 \mathrm{ppm}$ \\
\hline Arsenic, As & $1 \mathrm{ppm}$ & $1 \%$ \\
\hline Barium, Ba & $5 \mathrm{ppm}$ & $1 \%$ \\
\hline Beryllium, Be & $0.1 \mathrm{ppm}$ & 100 ppm \\
\hline Bismuth, Bi & 0.04 ppm & $1 \%$ \\
\hline Cadmium, Cd & $0.1 \mathrm{ppm}$ & $1 \%$ \\
\hline Cerium, Ce & 0.05 ppm & $0.10 \%$ \\
\hline Cobalt, Co & $0.1 \mathrm{ppm}$ & $1 \%$ \\
\hline Chromium, $\mathrm{Cr}$ & $1 \mathrm{ppm}$ & $1 \%$ \\
\hline Cesium, Cs & 0.05 ppm & $0.10 \%$ \\
\hline Copper, Cu & $0.5 \mathrm{ppm}$ & $1 \%$ \\
\hline Gallium, Ga & 0.05 ppm & 500 ppm \\
\hline Indium, In & $0.02 \mathrm{ppm}$ & $0.05 \%$ \\
\hline Lanthanum, La & $0.5 \mathrm{ppm}$ & $0.10 \%$ \\
\hline Lithium, Li & $1 \mathrm{ppm}$ & $5 \%$ \\
\hline Manganese, Mn & $5 \mathrm{ppm}$ & $1 \%$ \\
\hline Molybdenum, Mo & 0.05 ppm & $1 \%$ \\
\hline Niobium, $\mathrm{Nb}$ & $0.1 \mathrm{ppm}$ & $0.10 \%$ \\
\hline Nickel, Ni & $0.5 \mathrm{ppm}$ & $1 \%$ \\
\hline Lead, $\mathrm{Pb}$ & $0.5 \mathrm{ppm}$ & $1 \%$ \\
\hline Rubidium, Rb & $0.2 \mathrm{ppm}$ & $1 \%$ \\
\hline Sulfur, S & $0.01 \%$ & $5 \%$ \\
\hline Antimony, Sb & 0.05 ppm & $1 \%$ \\
\hline Scandium, Sc & $0.1 \mathrm{ppm}$ & $0.10 \%$ \\
\hline Tin, Sn & $0.1 \mathrm{ppm}$ & $0.10 \%$ \\
\hline Strontium, Sr & $0.5 \mathrm{ppm}$ & $1 \%$ \\
\hline Tellurium, Te & $0.1 \mathrm{ppm}$ & $0.05 \%$ \\
\hline Thallium, TI & $0.1 \mathrm{ppm}$ & $1 \%$ \\
\hline Thorium, Th & $0.2 \mathrm{ppm}$ & $1 \%$ \\
\hline Uranium, U & $0.1 \mathrm{ppm}$ & $1 \%$ \\
\hline Vanadium, V & $1 \mathrm{ppm}$ & $1 \%$ \\
\hline Tungsten, W & $0.1 \mathrm{ppm}$ & $1 \%$ \\
\hline Yttrium, Y & $0.1 \mathrm{ppm}$ & $1 \%$ \\
\hline Zinc, Zn & $1 \mathrm{ppm}$ & $1 \%$ \\
\hline
\end{tabular}


Selenium and antimony were analyzed by hydride generation-atomic absorption spectrometry (Hageman and Welsch, 1996). The reporting range for selenium was 0.2-4 ppm and for antimony was 0.6-20 ppm. Mercury was analyzed by cold vapor-atomic absorption spectrometry (O'Leary and others, 1996) with a lower reporting limit of $0.02 \mathrm{ppm}$. Carbonate carbon was determined as carbon dioxide by coulometric titration (Papp and others, 1996). The lower reporting limit is 0.01 percent carbon dioxide and the upper limit is $50 \%$ carbon dioxide. Total carbon was determined by an automated carbon analyzer in which a sample is combusted in an oxygen atmosphere at $1,370^{\circ} \mathrm{C}$ to oxidize carbon to carbon dioxide gas, which is measured by a solid state infrared detector (Curry, 1996a). The reporting range for total carbon is from 0.05 percent to about 30 percent. Total sulfur was determined by an automated sulfur analyzer in which a sample is combusted in an oxygen atmosphere at $1,370^{\circ} \mathrm{C}$ to oxidize sulfur to sulfur dioxide, which then is measured by a solid state infrared detector (Curry, 1996b). The reporting range for total sulfur is from 0.05 percent to about 35 percent.

\section{Quality Assurance}

The quality assurance program for the pilot study ensures that analytical results are within acceptable limits of precision (the reproducibility of results) and accuracy (the degree of conformity of results for a sample having known concentrations). Each laboratory job of 50 samples included blind duplicates of two samples and two blind standards of known concentration. In addition, between each analytical job, a separate job was analyzed consisting of multiple standard reference materials. Data were considered acceptable if recovery of all elements was \pm 15 percent at five times the lower limit of determination and if the calculated relative standard deviation of duplicate samples is no greater than 15 percent.

\section{Literature Cited}

Boerngen, J.G., and Shacklette, H.T., 1981, Chemical analyses of soils and other surficial materials of the conterminous United States: U.S. Geological Survey Open-File Report 81-197, 143 p.

Briggs, P.H., and Meier, A.L., 1999, The determination of forty-two elements in geological materials by inductively coupled plasma-mass spectrometry: U.S. Geological Survey Open-File Report 99-166, 15 p.

Curry, K.J., 1996a, Total carbon by combustion, in Arbogast, B.F., ed., Analytical methods manual for the Mineral Resource Surveys Program, U.S. Geological Survey: U.S. Geological Survey Open-File Report 96-525, p. 173-176.

Curry, K.J., 1996b, Total sulfur by combustion, in Arbogast, B.F., ed., Analytical methods manual for the Mineral Resource Surveys Program, U.S. Geological Survey: U.S. Geological Survey Open-File Report 96-525, p. 177-181.

Gough, L.P., Peard, J.L., Severson, R.C., Shacklette, H.T., Tompkins, M.L., Stewart, K.C., and Briggs, P.H., 1984, Chemical analyses of soils and other surficial materials, Alaska: U.S. Geological Survey Open-File Report 84-423, 77 p.

Gough, L.P., Severson, R.C., and Shacklette, H.T., 1988, Element concentrations in soils and other surficial materials of Alaska: U.S. Geological Survey Professional Paper 1458, 53 p. 
Gustavsson, N., Bølviken, B., Smith, D.B., and Severson, R.C., 2001, Geochemical landscapes of the conterminous United States-New map presentations for 22 elements: U.S. Geological Survey Professional Paper 1648, 38 p.

Hageman, P.L., and Welsch, Eric, 1996, Arsenic, antimony, and selenium by flow injection or continuous flow-hydride generation-atomic absorption spectrometry, in Arbogast, B.F., ed., Analytical methods manual for the Mineral Resource Surveys Program, U.S. Geological Survey: U.S. Geological Survey Open-File Report 96-525, p. 24-30.

Holmgren, G.G.S., Meyer, M.W., Chaney, R.L., and Daniels, R.B., 1993, Cadmium, lead, zinc, copper, and nickel in agricultural soils of the United States of America: Journal of Environmental Quality, v. 22, p. 335-348.

O'Leary, R.M., Hageman, P.L., and Crock, J.G., 1996, Mercury in water, geologic, and plant materials by continuous flow-cold vapor-atomic absorption spectrometry, in Arbogast, B.F., ed., Analytical methods manual for the Mineral Resource Surveys Program, U.S. Geological Survey: U.S. Geological Survey Open-File Report 96-525, p. 42-50.

Papp, Clara, Brandt, Elaine, and Aruscavage, Phillip, 1996, Carbonate carbon by coulometric titration, in Arbogast, B.F., ed., Analytical methods manual for the Mineral Resource Surveys Program, U.S. Geological Survey: U.S. Geological Survey Open-File Report 96-525, p. 60-66.

Shacklette, H.T., and Boerngen, J.G., 1984, Element concentrations in soils and other surficial materials of the conterminous United States: U.S. Geological Survey Professional Paper 1270, $105 \mathrm{p}$.

Shacklette, H.T., Boerngen, J.G., Cahill, J.P., and Rahill, R.L., 1973, Lithium in surficial materials of the conterminous United States and partial data on cadmium: U.S. Geological Survey Circular $673,8 \mathrm{p}$.

Shacklette, H.T., Boerngen, J.G., and Keith, J.R., 1974, Selenium, fluorine, and arsenic in surficial materials of the conterminous United States: U.S. Geological Survey Circular 692, 14 p.

Shacklette, H.T., Boerngen, J.G., and Turner, R.L., 1971a, Mercury in the environment-Surficial materials of the conterminous United States: U.S. Geological Survey Circular 644, 5 p.

Shacklette, H.T., Hamilton, J.C., Boerngen, J.G., and Bowles, J.M., 1971b, Elemental composition of surficial materials in the conterminous United States: U.S. Geological Survey Professional Paper 574-D, $71 \mathrm{p}$.

Tidball, R.R., 1984, Geochemical survey of Missouri-Geography of soil geochemistry of Missouri agricultural soils: U.S. Geological Survey Professional Paper 954-H, p. H1-H54. 


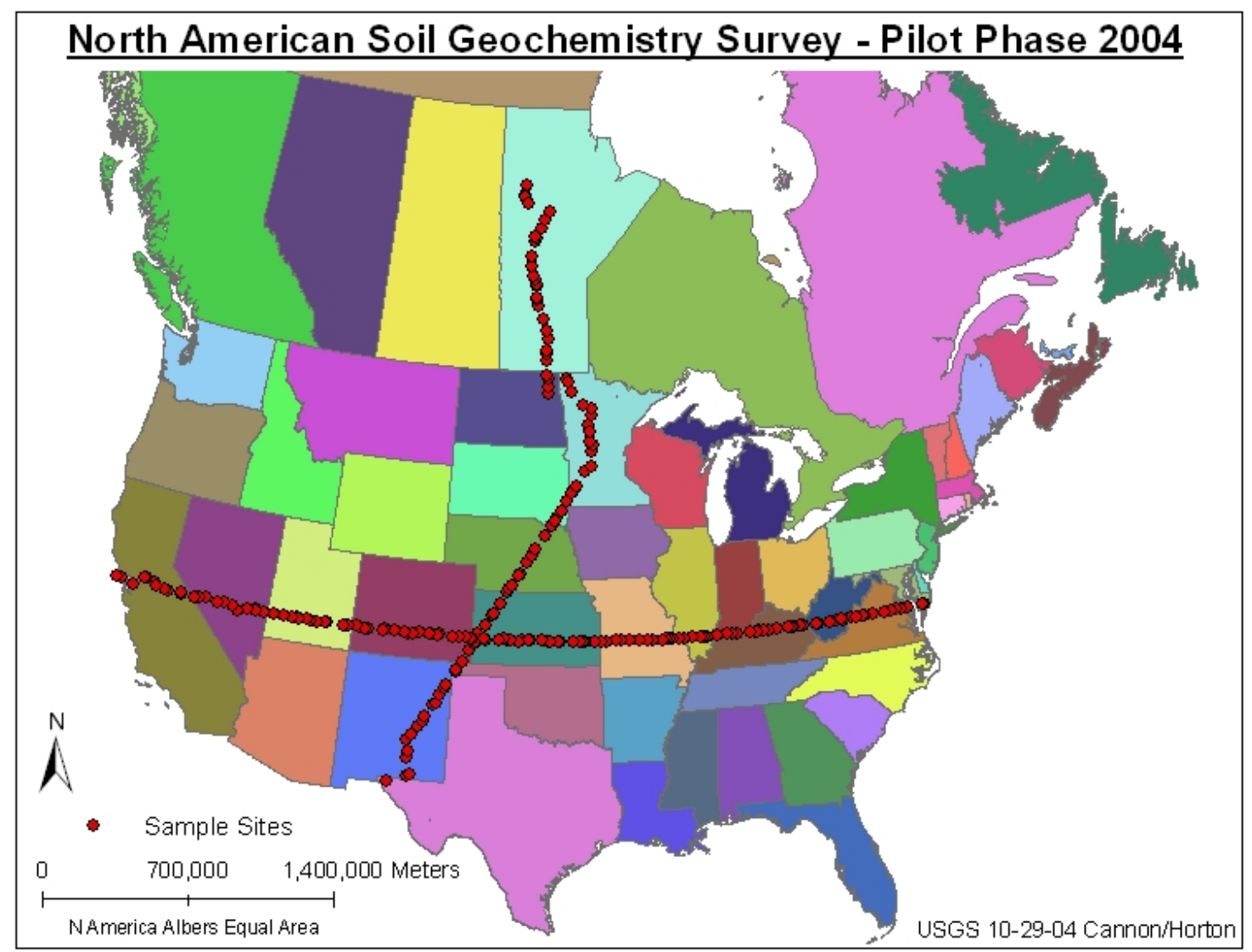

Figure 1. Locality map for samples collected along continental-scale transects. 


\section{Appendix 1: Soil Sampling Protocols for Geochemical Landscapes Pilot Studies-2004}

\section{General comments regarding criteria for site selection:}

1. Avoid sample sites nearer than 5 miles $(8 \mathrm{~km})$ downwind for known power plants, smelters, etc.

2. Avoid sample sites closer than about 200 meters from major highways.

3. Avoid sample sites closer than about 50 meters from rural roads.

4. Avoid sample sites closer than 100 meters from buildings.

5. Do not sample nearer than about 50 meters from end rows or other areas where large amounts of fertilizer could have been deposited.

6. Avoid any atypical or unusual landscapes, landforms, excessively disturbed ground, etc. (For example, mine dumps, landfills, construction sites.)

At each randomly selected site, the actual location where the sample is collected may be constrained by access. Common sense should prevail. Always request permission to sample on private land. Once an area is selected, determine a specific site that approximates the average landform of the area in view. For example, if you are in an area of mostly forested slopes and a few open fields, sample from the forested slopes. For sites within the United States, use the NRCS County Soil Survey maps and reports, if available, as a guide for site selection, identification of soil series sampled, and horizon depth and descriptions. Take several digital photographs of the area to be sampled, both of the surrounding area and the ground at the specific site. At each area, determine where each sample will be taken, and preserve the site until the sample is collected (i.e., do not walk all over the area to be sampled).

\section{Field Form:}

Filling out the field form is straightforward. Be neat and write legibly because all the information will be entered into a database.

1. Indicate what samples are collected at each site by checking the box.

2. The "Photographs From" field will be filled in if digital photographs are taken at the site. It is useful to include a piece of paper or a dry-erase board with the site number in the photos, if possible. Alternatively, take a "close up" of the piece of paper or dry-erase board showing the sample number immediately before a series of photographs of the site.

3. Latitude and longitude are collected as decimal degrees. Set up GPS accordingly.

4. Standardize coordinates on GPS to Map Datum WGS 84. If another map datum is preferred for an individual country, coordinates should be converted to WGS 84 for reporting purposes.

5. The "Landuse" field should include information related to cropland, range, etc. For example, Cropland, Rangeland, Wetland, etc. A complete list of landuse options is found in the following NRCS publication: Field Book for Describing and Sampling Soils, September 2002.

6. The "Landcover" field should include information related to the type of crop or range site. For example, sugarbeets, wheat, corn, hayland, silty rangesite, wetland rangesite.

7. Lots of room for comments-please comment liberally, as something of significance may be recorded inadvertently. 


\section{Samples to be collected:}

At each site for the continental-scale N-S and E-W transect, the following samples will be collected:

1. O horizon (if present) for chemical analysis - 1 sample bag (approximately $1 \mathrm{~kg}$ )

2. A horizon for chemical analysis -1 sample bag (approximately $1-2 \mathrm{~kg}$ )

3. C horizon for chemical analysis -1 sample bag (approximately $1-2 \mathrm{~kg}$ )

4. Composite of the A horizon (using sterile collection methods) for microbial characterization three sterile $50 \mathrm{ml}$ centrifuge tubes

5. Composite of the A horizon for determination of soil moisture -116 ounce (about $500 \mathrm{ml}$ ) plastic or metal container with screw top. The container must be watertight.

6. The top $5 \mathrm{~cm}$ of soil (regardless of horizon) for chemistry - 1 sample bag(approximately $1 \mathrm{~kg}$ )

7. The top $5 \mathrm{~cm}$ of soil (regardless of horizon) for analysis of organic compounds $-1500 \mathrm{ml}$ glass jar

The order in which the samples are collected is best determined by the individuals sampling and taking into consideration conditions at the site. At the first site of the day, it may be useful to take the samples for organic compounds and microbial characterization first, so a stainless steel bowl, trowel, and sieve then are available for all additional sampling. Weigh each of the stainless steel bowls and write the weight on the bowl-this is useful if the bowl is used to weigh soil samples.

\section{Soil sampling protocol for the $\mathbf{O}$ horizon, $\mathrm{A}$ horizon, and $\mathrm{C}$ horizon.}

For the purposes of this project the following definitions are used:

O horizon - Surface accumulations of mainly organic material; may or may not be, or has been saturated with water.

A horizon - Accumulation of humified organic matter mixed with mineral fraction; the latter is dominant. Occurs at the surface or below an $\mathrm{O}$ horizon.

C horizon - A subsurface horizon, excluding consolidated bedrock, like or unlike material from which the soil formed, or is presumed to have formed. Lacks properties of A and B horizons, but includes materials in various stages of weathering.

(From Soil Survey Division Staff [1993])

\section{Equipment needed:}

Standard soil bucket auger, with one or more extensions

Stainless steel or plastic trowels (2-3)

Plastic tarpaulin

Hubco ${ }^{\circledR}$ sample bags (approximately 7 inches $[17.8 \mathrm{~cm}]$ wide x 12.5 inches $[31.8 \mathrm{~cm}]$ deep)

Sharpie ${ }^{\circledR}$ permanent markers

Portable scale (for example, MyWeigh ${ }^{\circledR}$ briefcase scale)

Pinto beans (approximately 5 kilograms)

Plastic garbage bags

Tent stakes (4) and twine or string 
Stainless steel bowl (big enough to hold 2-3 kilograms of pinto beans)

Soil $\mathrm{pH}$ meter (optional)

Shovel (sharpshooter or similar long-nose variety)

Rock hammer

Knife

2-mm stainless steel sieve

Sealable plastic bags (1 gallon)

Handheld GPS unit

Digital camera

Extra batteries for GPS, camera, and scale

For the O- and A-horizon samples, it may be useful for some purposes to convert from concentration data to loads (i.e., from $\mathrm{ppm}$ to grams/meter ${ }^{2}$ or grams/meter ${ }^{3}$ ). For this reason, we describe a volumetric sampling procedure for those horizons.

Volumetric sampling of $\mathbf{O}$ horizon or organic litter: (Because the thickness of the $\mathrm{O}$ horizon is frequently very small $(1-2 \mathrm{~cm})$ and so compressible that the thickness is difficult to determine accurately, we get a weight of $\mathrm{O}$ material per unit area rather than density. This still gives us the ability to calculate the amount of each element per unit area.) To volumetrically sample the $\mathrm{O}$ horizon, at each site lay out a $60 \mathrm{~cm}$ by $60 \mathrm{~cm}$ area (about $2 \mathrm{ft}^{2}$ ), using tent pegs to mark the corners and outline the measured area with string or twine. Record the actual area on the field form. Use a knife to cut into the soil along the margins of the string to restrict sample material to measured area. Within this area, collect all the O-horizon or litter material lying on the mineral soil; exclude live vegetation, woody debris, cones, droppings, charcoal, and roots. Place all collected material on a plastic garbage bag and pick through by hand, cleaning and homogenizing, to remove any remaining wood or live plants. The distinction between the $\mathrm{O}$ horizon and mineral soil can be somewhat arbitrary, but often is based on feel (grainy [mineral] vs. soft [organic]) and hand lens observation. If the $\mathrm{O}$ horizon is thick, measure the approximate depth at several points in the area to help calculate the volume of material removed. Record this information in the comments section of the field form.

All of the organic material collected from within the square is weighed, with the total weight recorded on the field form. A representative portion of the $\mathrm{O}$ horizon material then is collected into a sample bag or similar container. If the amount of material from within the square does not fill the bag, additional comparable material may be collected from nearby. About 200-300 grams of material are required for chemical analysis plus additional material is needed for archival purposes. If possible, collect about $1 \mathrm{~kg}$ of

O-horizon material. Label the sample bag with the site number and "O-horizon/litter". Weigh the filled sample bag and record on both the field form and on the bag. Do not subtract the weight of the sample bag - this can be checked later. Prior to submission for analysis, the air-dried sample bag will be reweighed, and a final weight for the entire O-horizon sample within the measured area is recalculated based on the percentage weight change from wet to dry, and from the original bulk weight. Do not store O-horizon/litter sample in a plastic bag as it can mold.

Volumetric sampling of the A horizon: The A horizon usually is thick enough to permit an accurate measurement of depth to the A-B boundary. For this reason, volumetric sampling of the A horizon uses the weight and volume of soil collected to calculate a bulk soil density. This requires an accurate measurement of the depth of the A horizon, preferably accurate to less than $2 \mathrm{~cm}$. The 
A horizon can be collected from the area used for collection of the $\mathrm{O}$ horizon, or from anywhere considered to be typical. Remove any living plants. If the sample is collected from inside the Ohorizon square, start in the middle of the square. Using a shovel and(or) trowels, collect the A horizon down to what is determined to be the top of the B horizon, a distinction usually based on color change. In areas of thick A horizons, it is efficient to dig a small hole using the shovel or trowel, and then carefully auger to the base of the A, checking often for color change. This creates a fairly small volume suitable for estimating volume by the cavity compensation method described below.

Place all soil from the sampled volume onto a plastic garbage bag or into a stainless steel bowl. This bulk soil sample is then weighed on a portable field balance-if weighed in a bowl, note the weight of the bowl to subtract from the total weight. If rocks, roots, and woody debris represent a significant proportion of the volume, sieve the sample using a 2-mm stainless steel sieve. Sieve the entire quantity of A-horizon soil removed and weigh the sieved soil, entering the value onto the field sheet. If it is not possible to sieve (e.g., too wet or too much clay), or if there would be little difference between the sieved and unsieved weights, then estimate the approximate volume that was occupied by any rocks or roots that were removed - this will make the volume calculation more accurate. In other words, estimate what percentage of the volume (not weight) was occupied by things other than soil. Make a note on the field form of actions taken for the A-horizon sieving.

The volume of the A horizon is calculated by a method known as cavity compensation. This involves filling the excavated hole with a material whose weight-to-volume ratio is known. This material then is removed from the hole, weighed, and the volume calculated. We have found that dried pinto beans work very well for this purpose. First, weigh the container with all the pinto beans to establish a baseline. Line the excavated hole with a plastic bag (if the hole has been augered, make sure the bag goes all the way to the base of the hole). Pour the beans into the excavated hole until the beans are level with the original surface. Weigh the container with the remaining beans to determine the weight of the beans filling the hole by difference (do not weigh the beans in the hole). This process should be repeated 2 more times to obtain an average weight. It is not necessary to completely remove all the beans from the hole. Remove several handfuls of the beans from the hole and place them back in the container. Now refill the hole to the surface and weigh the container to determine the weight of the beans in the hole by difference. Record the measured weights of the beans remaining in the container on the field form-you can subtract this from the total weight of the beans to determine the weight of beans in the hole and obtain the average later. When the arithmetic is completed, the calculated weight of beans in the hole will be entered on the field form. This weight can be extrapolated into a volume by a formula determined in the laboratory by multiple weighings of beans in fixed volumes. This can be accomplished by using a large graduated cylinder or similar container with graduated volume markings.

Collect a representative subsample of the A-horizon material from the bowl or plastic bag and place into a sample bag - about 1-2 kilograms are required. Label the sample bag with the site number and A horizon. Weigh the filled sample bag and record the weight both on the field form and on the bag label. Do not subtract the weight of the sample bag-this can be checked later. Measure the depth interval of the A horizon (assumed to start at 0 centimeters) and record the depth interval on the field form - accuracy is important! Any left-over soil should be used to refill the hole when all sampling is complete. 
Prior to submission for analysis, the air-dried sample bag will be reweighed and a final weight for the entire A horizon is recalculated on the percentage weight change from wet to dry, and from the original bulk weight.

C horizon: No volumetric sample is required. The C-horizon sample is collected from the Ahorizon hole or from a separate hole using a bucket auger, shovel, or trowel. Auger or dig to the best depth estimate for the $\mathrm{C}$ horizon, or until bedrock is encountered. For sites in the United States, the NRCS soil survey data may be used as a guide. In especially deep soils, dig as deep as possible, at least 1 meter-more if possible. This may require some maneuvering around smaller rocks, or angle augering. Try to ensure that the shovel hole is free of A-horizon material, which may become smeared through the C-horizon sample by the auger. If necessary, each auger volume should be laid out on a plastic tarpaulin or plastic bag in order to observe color change to aid in identification of the different soil horizons. Collect a representative portion of the $\mathrm{C}$ horizon into a sample bag (1-2 kilograms) and label bag with the site location and

C horizon. Remove as many of the rocks as practical-the more rocks, the smaller the amount of sample remaining after sieving. On the field form, record the depth interval from which the sample was collected.

\section{Soil sampling of the A horizon for microbiological characterization}

\section{Equipment needed:}

Sterile 50-mL centrifuge tubes with screw cap (3)

Rubbing alcohol

Nitrile gloves

Sterile stainless steel bowl (can be same bowl used in organic sampling, just be sure to clean and sterilize with alcohol)

Sterile stainless steel (or plastic) trowel

Cooler with blue ice or freezer for storing samples

Cooler with blue ice for shipping samples

Strapping tape for sealing cooler for shipping

Sharpie ${ }^{\circledR}$ permanent marker

Large sealable (3 gallons or more) plastic bags or plastic storage containers for holding sampling equipment for one site)

Small sealable plastic sandwich bags for storing centrifuge tubes after sampling Kimwipes ${ }^{\circledR}$

The important consideration in sampling soil for microbiological characterization is to use only sterile tools and sample containers and to wear nitrile gloves during sampling. If a hole from which the sample is to be taken was dug with a nonsterile shovel or auger, then the sides of the hole should be scraped "clean" with a sterile stainless steel (or plastic) trowel prior to sampling. This is to eliminate any cross-contamination from previous holes dug with the same shovel or auger. If the same trowel is to be used for collecting the sample, then it should be resterilized by wiping with rubbing alcohol.

A composite of the A-horizon soil is the sample medium for microbiological characterization. If the A horizon is shallow, then the soil may be sampled directly by using a sterile stainless steel (or plastic) trowel. If the A horizon extends to a depth beyond which can be easily reached with the 
trowel, then a hole should be dug with a shovel or auger. If this is the case, then scrape the sides of the hole from which the sample will be collected with a sterile stainless steel (or plastic) trowel to avoid contamination from previous holes dug with the same shovel or auger. Using a sterile trowel, place the soil into a sterile glass or stainless steel bowl to homogenize. Then place the homogenized material into three (3) sterile 50-mL centrifuge tubes (or similar sterile containers). Fill each tube as full as possible. We normally place the three tubes from each site into a zip lock plastic bag for storage in a cooler or freezer. The samples must be kept cold from the time of sampling. [Note: Any sample collected for BioLog characterization should not be frozen, but should be kept cold. Any sample collected for phospholipid fatty acid analysis and(or) pathogen screening may be frozen.] If a portable freezer is available, place the samples in the freezer and freeze. If a freezer is not available, place the samples into a cooler and keep on ice. Unless a freezer is available, the samples should be sent on ice in a cooler by overnight mail so they arrive at the laboratory within 3 days of collection. If a freezer is available, then the samples can be sent to the labs when convenient.

\section{Soil Sampling of the A Horizon for Determination of Moisture Content}

\section{Equipment needed:}

16 ounce $(500 \mathrm{~mL})$ polypropylene jars or similar watertight container (can be plastic or metal) Trowel

Shovel

Plastic garbage bag

Portable scale

Collecting a sample of the A horizon for determination of soil moisture requires no special equipment other than a watertight container. A $500 \mathrm{~mL}$ (16 ounce) or similar size container is adequate. Simply take a composite of the A horizon using a trowel or shovel and place a representative sample into the watertight container. It is probably advisable to weigh the container plus soil onsite and to record this weight on the field form and on the jar. Assuming no moisture is lost from the container, this weighing can be performed in the laboratory as well. Once in the laboratory, the soil will be dried and weighed; the moisture content being the difference between the wet weight and the dry weight.

\section{Soil Sampling of the Top $5 \mathrm{~cm}(0-5 \mathrm{~cm})$}

\section{Equipment needed:}

Stainless steel or plastic trowel Hubco® sample bags (approximately 7 inches $[17.8 \mathrm{~cm}]$ wide x 12.5 inches $[31.8 \mathrm{~cm}]$ deep) Plastic garbage bag or stainless steel bowl

Portable field scale

The topmost $5 \mathrm{~cm}$ of soil is the preferred sample medium of the public health community. This is the material that people most often come into contact with when walking, sitting, lying, or playing on the ground. Thus, this is the most important medium for health issues concerning chronic exposure to potentially toxic elements or compounds in soils. Volumetric sampling is required to 
convert concentration data to loads ( $\mathrm{ppm}$ to grams $/ \mathrm{m}^{2}$ or grams $/ \mathrm{m}^{3}$ ). If the $0-5 \mathrm{~cm}$ interval is entirely within the A horizon, then the density calculated for the A horizon (using the cavity compensation method explained above) can be applied to this sample and no additional volumes need be determined. If this is the situation, simply excavate an area down to $5 \mathrm{~cm}$ and place the material in the sample bag, removing roots and rocks. About 1-2 kg is needed. Label the bag with the site name and 0-5 cm Environmental Health.

However, if the 0-5 cm interval includes the $O$ horizon, then the density of the mixed material must be determined by volumetric sampling. For the volumetric measurement by the cavity compensation method, follow the procedure described for the A-horizon sample. In short, excavate a volume down to $5 \mathrm{~cm}$ and put the soil onto a plastic bag or into a stainless steel bowl. Calculate the volume of the hole using the pinto bean method described for the A horizon. Weigh all of the soil removed from the hole and record the weight on the field form. Place the sample into a sample bag and weigh the bag, recording the weight both on the field form and on the bag. Label the bag with the site name and 0-5 cm Environmental Health.

\section{Soil Sampling for Organic Compounds $(0-5 \mathrm{~cm})$}

Equipment needed:

$500 \mathrm{~mL}$ baked amber glass jars

Stainless steel 10-mesh (2-mm) sieve

Stainless steel trowel

Stainless steel or glass bowl

Heavy-duty aluminum foil

Pesticide-grade or residue-grade methanol

Phosphate-free detergent

Large sealable plastic bags (3-gallon size or larger) or plastic containers (for storing and transporting cleaned equipment.

Labels

Cooler with blue ice or portable freezer

Cooler with blue ice for shipping samples

Strapping tape for sealing cooler

Sharpie ${ }^{\circledR}$ permanent markers

Bubble wrap for cushioning jars during shipping (can use newspapers or foam worms)

The important point in taking soil samples to be analyzed for organic compounds is to use only equipment made of stainless steel, Teflon, or glass. All the equipment should be cleaned prior to sampling by washing in water and a phosphate-free detergent such as Liqui-Nox® and then a final rinse with pesticide-grade or residue-grade methanol. The cleaned sampling equipment then is wrapped in heavy-duty aluminum foil and stored for transportation to the field in either a large (3-gallon size or larger) sealable plastic bag or in a plastic storage container. It is certainly an acceptable alternative to clean all the equipment between each site, but it is much easier to do all of this where you have a bathtub or sink and plenty of water. We have been preparing four separate sampling "kits" prior to each day in the field.

The sample is taken from $0-5 \mathrm{~cm}$ regardless of what horizon this might be. Using the properly cleaned stainless steel trowel, take soil from $0-5 \mathrm{~cm}$ and place into the cleaned stainless steel 2-mm 
sieve. Sieve the material into a cleaned glass or stainless steel bowl and then transfer into the 500 $\mathrm{ml}$ baked glass jars. Try to fill the jar reasonably full. Label the jar and the screw cap, put the cap in place and then put the jar into either a portable freezer or cooler. It is important to keep the sample cold. If a portable freezer is not available, then the samples must be shipped by overnight service so that the samples are in the laboratory where a freezer is available within 3 days of collection. If a portable freezer is available, then keep the samples frozen until returned to the laboratory or until it is convenient to ship to the labs by overnight shipping. 


\section{Data Section}

[All data tables in this section are sorted first by transect (E-W or N-S) then by state within each transect. Latitude and longitude coordinates are degraded to only one decimal place to prevent sample sites being associated with any specific parcel of privately owned property. All chemical data are given on a dry weight basis.] 


\section{Terms and Abbreviations}

The following terms and abbreviations are used in tables 2-5:

$\begin{array}{ll}\text { Army Core Engr } & \text { U.S. Army Core of Engineers } \\ \text { BLM } & \text { U.S. Bureau of Land Management } \\ \text { cm } & \text { centimeter } \\ \text { Combust. } & \text { Combustion } \\ \text { COUL TITR } & \text { Coulometric titration } \\ \text { CRBNT_C } & \text { Carbonate carbon } \\ \text { CVAA } & \text { Cold vapor atomic absorption } \\ \text {-dup } & \text { duplicate sample } \\ \text { FS } & \text { U.S. Forest Service } \\ \text { GRS80 } & \text { Geodetic Reference System 1980 } \\ \text { Hyd } & \text { Hydride generation atomic absorption spectrometry } \\ \text { ICPAES_MS } & \text { Inductively coupled plasma atomic emission spectrometry } \\ & \text { and inductively coupled plasma mass spectrometry } \\ \text { in } & \text { inch } \\ \text { NAD83 } & \text { North American Datum of 1983 } \\ \text { ppm } & \text { parts per million } \\ \text { Tot C } & \text { Total carbon } \\ \text { Tot S } & \text { Total sulfur } \\ \text { WGS84 } & \text { World Geodetic System 1984 } \\ < & \text { less than }\end{array}$


Table 2. Major and trace-element data for soils collected at a depth of 0-5 cm.

Table 3. Major and trace-element data for A-horizon soils.

Table 4. Major and trace-element data for C-horizon soils.

Table 5. Major and trace-element data for 0-horizon soils. 